\title{
Effect of Cement Variation on Properties of CLC Concrete Masonry Brick
}

\author{
Erwin Sutandar ${ }^{1, *}$, Asep Supriyadi ${ }^{1}$, and Cek Putera Andalan ${ }^{1}$ \\ ${ }^{1}$ Universitas Tanjungpura, Civil Engineering Department, Prof. Dr. Hadari Nawawi Street, \\ Pontianak, West Kalimantan, Indonesia
}

\begin{abstract}
One of the methods used to reduce the weight of a construction is by reducing the weight of the walls of the building. In such a case, a wall made of red brick has a volume weight of $1,500-2,000 \mathrm{~kg} / \mathrm{m}^{3}$, and concrete masonry bricks made of CLC have a volume weight of $400-1,800 \mathrm{~kg} / \mathrm{m}^{3}$. So, in comparison, concrete masonry bricks have a volume weight that is $\leq$ $50 \%$ of that of red brick. In the manufacturing of concrete masonry bricks, one variant is CLC (Cellular Lightweight Concrete), produced using a mixture of cement, sand, chemical admixture and water, with the filler material in the form of air generated as microscale soap bubbles (microbubbles), also known as foam agent. In the manufacturing of concrete masonry bricks, the cement as a binder material clearly affects the physical and mechanical properties of the bricks produced. This research is conducted to investigate the effect of the amount or composition of the cement used on the physical and mechanical properties of concrete masonry bricks. The composition is varied among 200, 250, 300, 350 and $400 \mathrm{~kg} / \mathrm{m}^{3}$ of cement usage.
\end{abstract}

\section{Introduction}

For the purpose of lightweight construction in soft soil or peatland areas, innovation is required to reduce the self-weight of the construction. One way to reduce this is by reducing the weight of the walls, which are generally made of red brick having a volume weight of $1,500-2,000 \mathrm{~kg} / \mathrm{m}^{3}$ [5], cement brick with a volume weight of $950-1,000 \mathrm{~kg} / \mathrm{m}^{3}$ [6][7] or CLC masonry concrete brick with a lighter volume weight of $400-900 \mathrm{~kg} / \mathrm{m}^{3}$ [1]. This CLC masonry concrete brick also has the effect of reducing the reinforcement of a structure, as a result of the lower section dimensions of the structural elements, and it reduces the amount of concrete, avoiding the usage of sand in the plaster, making the building more economical [6][7].

CLC masonry concrete brick can be used as an alternative to red brick, to reduce environmental pollution and global warming. CLC masonry concrete brick is environmentally friendly. The energy consumed in the production of this type of masonry lightweight concrete brick is less than for the production of red brick, and it also neither produces pollution nor creates toxic products or have any impact on the environment [12]. This is because CLC masonry lightweight concrete brick is made of a mixture of cement, sand, water, and chemical admixture, to which is then added a foam that is stable in an

\footnotetext{
* Corresponding author: erwin_sutandar@yahoo.com
} 
ordinary concrete mixer. The addition of foam to the CLC mixture creates millions of voids or small cells in the material, which is why it is given the name of CLC masonry concrete brick.

Cement, as one of the basic ingredients of CLC masonry concrete bricks, is a binder that aggregates granules into a solid form. In using cement as a binding agent, the physical and mechanical properties of the CLC masonry concrete brick are determined by the composition of the cement to be used, and determining the optimum composition in terms of cement consumption when manufacturing the lightweight concrete brick will ensure the optimal results. Therefore, research is needed to compare the physical and mechanical properties of the CLC masonry concrete brick that is produced.

\section{Material and Dimensions of CLC Masonry Concrete Brick}

\subsection{Cement}

Commercially available cement is used, namely Holcim cement type III (i.e. ASTM C 15095a \& SNI 15-2049-1994 \& BS 12:1989) with the strength of the initial high Portland Composite Cement (PPC) and a specific gravity of $2,950 \mathrm{~kg} / \mathrm{m}^{3}$ [11]. The physical and chemical properties of the PCC cement can be seen in Table 1.

Table 1. Physical and chemical properties of cement [3][11]

\begin{tabular}{|l|c|}
\hline \multicolumn{2}{|l|}{ A. Compression Strength } \\
\hline 3 day & $\min 13 \mathrm{MPa}$ \\
\hline 7 day & $\min 20 \mathrm{MPa}$ \\
\hline 28 day & $280 \mathrm{MPa}$ \\
\hline Fineness & \multicolumn{2}{|c|}{} \\
\hline B. Time Settings & $45 \mathrm{mins}$ \\
\hline Initial & $375 \mathrm{mins}$ \\
\hline Final & $23.04 \%$ \\
\hline C. Chemical properties & $7.40 \%$ \\
\hline Silicon Dioxide $\left(\mathrm{SiO}_{2}\right)$ & $3.36 \%$ \\
\hline Aluminium Oxide $\left(\mathrm{Al}_{2} \mathrm{O}_{3}\right)$ & $57.38 \%$ \\
\hline Ferric Oxide $\left(\mathrm{Fe}_{2} \mathrm{O}_{3}\right)$ & $1.91 \%$ \\
\hline Calcium Oxide $(\mathrm{CaO})$ & $2.0 \%$ \\
\hline Magnesium Oxide $(\mathrm{MgO})$ & $3.94 \%$ \\
\hline Sulphur Trioxide $\left(\mathrm{SO}_{3}\right)$ & $0.56 \%$ \\
\hline Loss on Ignition $(\mathrm{LOI})$ & $10.96 \%$ \\
\hline Free Lime & \\
\hline Insoluble Residue &
\end{tabular}

\subsection{Fine Aggregate}

Fine aggregate as one of the components in cement must undergo a series of tests on the properties and characteristics of the material. In this study, the type of fine aggregate used is yellow sand (SNI-03-2834-2002) and the qualification limits determined for the fine aggregate are classified into four groups based on the degree of smoothness of the sand material [13]. This research includes sand zone III with a fines modulus of 3.030 [3]. 


\subsection{Water}

The water used is taken from the local water company with a pH 6-7 (SNI 03-2874-2002 and meeting the requirements of PBBI 1971 NI-2).

\subsection{Foaming Agent}

Foamed concrete is produced by either a pre-foaming method or a mixed foaming method. The pre-foaming method involves the separate production of a base mix cement slurry (cement paste or mortar) and a stable preformed aqueous addition (foam agent with water), and this foam is then thoroughly blended into the base mix. In mixed foaming, the surface active agent is mixed with the base mixture ingredients and, during the process of mixing, the foam is produced, resulting in a cellular structure in the concrete as shown in Fig. 1. The preformed foam can be either wet or dry. Wet foam is produced by spraying a solution of foaming agent over a fine mesh, has a $2-5 \mathrm{~mm}$ bubble size, and is relatively less stable. Dry foam is produced by forcing the foaming agent solution through a series of highdensity restrictions and forcing compressed air simultaneously into the mixing chamber. Dry foam is extremely stable and has a size smaller than $1 \mathrm{~mm}$. Table 2 shows the properties of foamed concrete [1].

Table 2. Typical properties of foamed concrete [1]

\begin{tabular}{|c|c|c|c|c|}
\hline $\begin{array}{c}\text { Dry } \\
\text { density } \\
\left(\mathrm{kg} / \mathrm{m}^{3}\right)\end{array}$ & $\begin{array}{c}\text { Compression } \\
\text { strength } \\
(\mathrm{MPa})\end{array}$ & $\begin{array}{c}\text { Modulus of } \\
\text { elasticity (E- } \\
\text { value) }(\mathrm{GPa})\end{array}$ & $\begin{array}{c}\text { Thermal } \\
\text { conductivity }(3 \% \\
\text { moisture })(\mathrm{W} / \mathrm{mK})\end{array}$ & $\begin{array}{c}\text { Drying } \\
\text { shrinkage } \\
(\%)\end{array}$ \\
\hline 400 & $0.5-1.0$ & $0.8-1.0$ & 0.10 & $0.30-0.35$ \\
\hline 600 & $1.0-1.5$ & $1.0-1.5$ & 0.11 & $0.22-0.25$ \\
\hline 800 & $1.5-2.0$ & $2.0-2.5$ & $0.17-0.23$ & $0.20-0.22$ \\
\hline 1000 & $2.5-3.0$ & $2.5-3.0$ & $0.23-0.30$ & $0.15-0.18$ \\
\hline 1200 & $4.5-5.5$ & $3.5-4.0$ & $0.38-0.42$ & $0.09-0.11$ \\
\hline 1400 & $6.0-8.0$ & $5.0-6.0$ & $0.50-0.55$ & $0.07-0.09$ \\
\hline 1600 & $7.5-10$ & $10.0-12.0$ & $0.62-0.66$ & $0.06-0.07$ \\
\hline
\end{tabular}

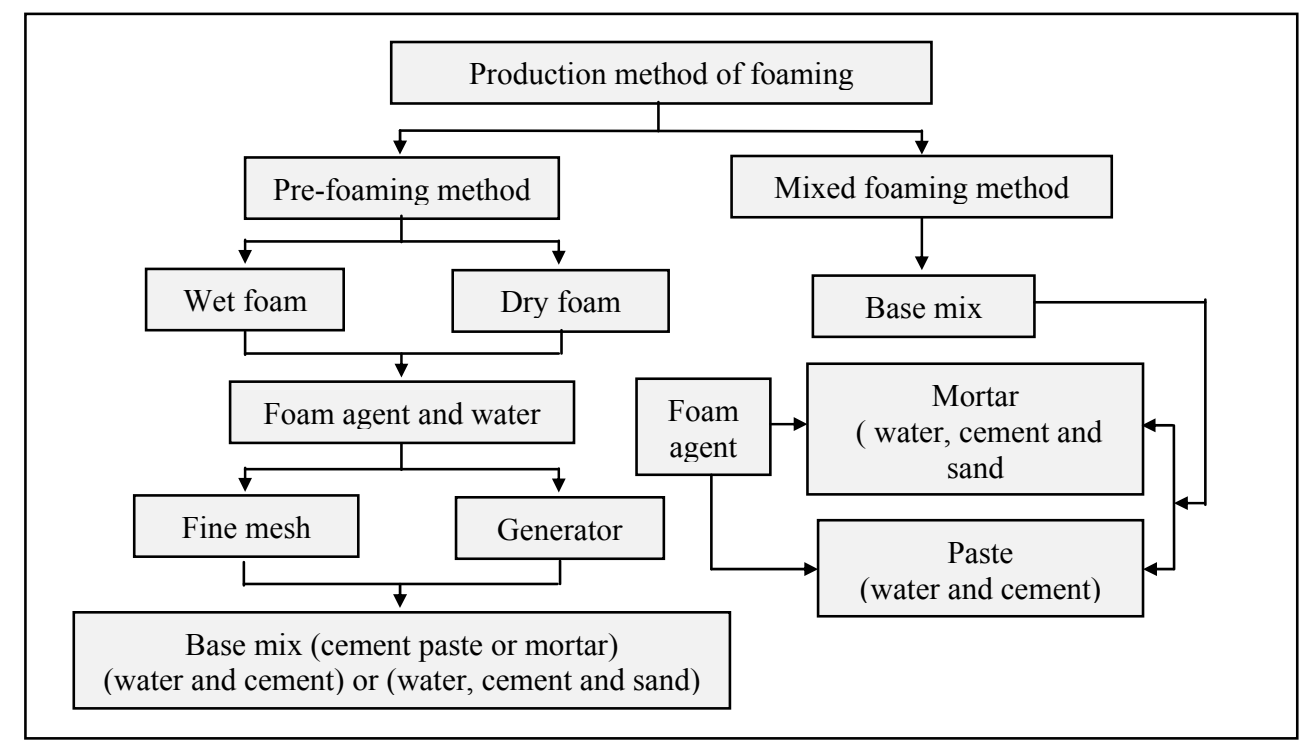

Figure 1. Classification process of production method for foamed concrete 
The container holding the foaming agent must be kept airtight and under temperatures not exceeding $25^{\circ} \mathrm{C}$. Once diluted in 80 parts of potable water, the emulsion must be used as soon as possible. The weight of the foam solution used is a minimum of $80 \mathrm{~g} / \mathrm{l}$, the containment solution used is as close as possible to 10 litres in volume, to check the weight (density) of the foam. Under no circumstances must the foaming agent should not contact with any oil or fat, chemical or other material that might harm its function (oil has an influence on the surface tension of water) [6] [10]. The foaming agent used is a brand under the trademark ADT.

\subsection{Chemical Admixture}

The chemical admixture is usually used in small amounts in the concrete mix. Its use is intended to improve certain properties of the mixture. The materials used are a high-range water-reducing admixture, wherein the material can reduce the water demand of the cement by up to a maximum of $15 \%$. The product Sikament LN from Sika Company is a type of chemical additive used as a water reducer and to speed up the hardening of mortar that requires an immediate settling time or an accelerator. Sikament LN is an admixture classified as ASTM C494-92 type F [2]. With Sikament LN, the composition uses a dose rate of $0.40 \%$ of the total cement requirement of $300 \mathrm{~kg}$, so the quantity needed for this experiment is as much as $1.2 \mathrm{~kg}$.

\subsection{Dimensions of the test objects}

The nominal dimensions of the CLC brick of the United States standard are as follows: length: $600 \mathrm{~mm}$, height: $200 \mathrm{~mm}$, width: $75 \mathrm{~mm}$. And the dimensions for modulus of elasticity testing diameter $150 \mathrm{~mm}$ and height $300 \mathrm{~mm}$ [5][6].

\section{Experimental}

This stage of the study involves the design of the mixture that will be used in the creation of samples of CLC masonry lightweight concrete brick. This variation plan is created as a guide to the composition of the mixture that will be investigated in this research and is presented in Table 3.

Table 3. Composition of the basic materials of samples [3][8]

\begin{tabular}{|c|c|c|c|c|c|c|c|}
\hline \multirow{2}{*}{ No } & \multirow{2}{*}{ Ingredients } & \multicolumn{5}{|c|}{ Number $/ \mathrm{m}^{3}$} & \multirow{2}{*}{ Units } \\
\hline & & V1 & V2 & V3 & V4 & V5 & \\
\hline 1 & Cement & 200 & 250 & 300 & 350 & 400 & $\mathrm{~kg}$ \\
\hline 2 & Sand & \multicolumn{5}{|c|}{500} & $\mathrm{~kg}$ \\
\hline 3 & Foam agent and water & \multicolumn{5}{|c|}{64.8} & litres \\
\hline 4 & Water & \multicolumn{5}{|c|}{150} & $\mathrm{~kg}$ \\
\hline 5 & Sikament LN & \multicolumn{5}{|c|}{1.2} & $\mathrm{~kg}$ \\
\hline
\end{tabular}

\section{Results and Discussion}

From the research that has been done, the findings obtained based on the test results, i.e. according to ASTM and ACI standards, can be seen in Table 4. 
Table 4. Comparison of the results for different amounts of cement in the making of CLC masonry concrete brick

\begin{tabular}{|c|c|c|c|c|c|c|}
\hline No & Parameters & $\begin{array}{c}\text { Cement } \\
200 \\
\mathrm{~kg} / \mathrm{m}^{3}\end{array}$ & $\begin{array}{c}\text { Cement } \\
250 \\
\mathrm{~kg} / \mathrm{m}^{3}\end{array}$ & $\begin{array}{c}\text { Cement } \\
300 \\
\mathrm{~kg} / \mathrm{m}^{3}\end{array}$ & $\begin{array}{c}\text { Cement } \\
350 \\
\mathrm{~kg} / \mathrm{m}^{3}\end{array}$ & $\begin{array}{c}\text { Cement } \\
400 \\
\mathrm{~kg} / \mathrm{m}^{3}\end{array}$ \\
\hline 1 & $\begin{array}{l}\text { Success rate of CLC } \\
\text { brick making (\%) }\end{array}$ & 33 & 100 & 100 & 100 & 100 \\
\hline 2 & Slump flow (mm) & 280 & 280 & 275 & 275 & 280 \\
\hline 3 & Drying shrinkage $(\%)$ & 31.13 & 0 & 0 & 0 & 0 \\
\hline 4 & Porosity $(\%)$ & 0 & 23.93 & 27.64 & 42.30 & 25.38 \\
\hline 5 & Sound resistance $(\mathrm{db})$ & 0 & 49.38 & 34.94 & 31.10 & 50.57 \\
\hline 6 & $\begin{array}{l}\text { Thermal conductivity } \\
(\mathrm{W} / \mathrm{mK})\end{array}$ & 0 & 0.55 & 0.57 & 0.47 & 0.55 \\
\hline 7 & $\begin{array}{l}\text { Permeability } \\
\text { (cm/second) }\end{array}$ & 0 & $\begin{array}{c}2.77 x \\
10^{-5}\end{array}$ & $\begin{array}{c}1.62 \mathrm{x} \\
10^{-5}\end{array}$ & $\begin{array}{c}2.60 \mathrm{x} \\
10^{-5}\end{array}$ & $\begin{array}{c}2.96 \mathrm{x} \\
10^{-5}\end{array}$ \\
\hline 8 & $\begin{array}{l}\text { Modulus of elasticity } \\
(\mathrm{MPa})\end{array}$ & 0 & 51.00 & 45.74 & 98.64 & 75.23 \\
\hline 9. & $\begin{array}{l}\text { Dry volume weight at } \\
\text { the age of } 28 \text { days } \\
\left(\mathrm{kg} / \mathrm{m}^{3}\right)\end{array}$ & 0 & 851 & 895 & 749 & 842 \\
\hline 10 . & $\begin{array}{l}\text { Compressive strength } \\
(\mathrm{MPa})\end{array}$ & 0 & 0.82 & 1.28 & 0.56 & 0.68 \\
\hline 11. & Absorption (\%) & 0 & 16.02 & 29.11 & 37.85 & 28.69 \\
\hline
\end{tabular}

\section{Conclusion}

The different compositions studied included the use of $200 \mathrm{~kg} / \mathrm{m}^{3}, 250 \mathrm{~kg} / \mathrm{m}^{3}, 300$ $\mathrm{kg} / \mathrm{m}^{3}, 350 \mathrm{~kg} / \mathrm{m}^{3}$ and $400 \mathrm{~kg} / \mathrm{m}^{3}$ of cement. From the research conducted, it was found that the cement composition affects the physical and mechanical properties of concrete masonry bricks, including the success rate of CLC brick making, volume weight, compressive strength and others.

The research results show that the CLC masonry concrete brick variants that qualified as brick CLC included only the cement proportions of $250 \mathrm{~kg} / \mathrm{m}^{3}, 300 \mathrm{~kg} / \mathrm{m}^{3}, 350 \mathrm{~kg} / \mathrm{m}^{3}$ and $400 \mathrm{~kg} / \mathrm{m}^{3}$, while the cement sample with $200 \mathrm{~kg} / \mathrm{m}^{3}$ cannot be recommended for use as a successful mixture for producing CLC masonry bricks because of the drying shrinkage seen at the age of just 1 day.

The use of different cement compositions of $200 \mathrm{~kg} / \mathrm{m}^{3}, 250 \mathrm{~kg} / \mathrm{m}^{3}, 300 \mathrm{~kg} / \mathrm{m}^{3}, 350$ $\mathrm{kg} / \mathrm{m}^{3}$ and $400 \mathrm{~kg} / \mathrm{m}^{3}$ has an influence on the physical and mechanical properties of the CLC masonry concrete bricks produced, as can be seen in Table 4. The results of the research show that the average volume weight is $749-895 \mathrm{~kg} / \mathrm{m}^{3}$. The lightest variant is the sample using $350 \mathrm{~kg} / \mathrm{m}^{3}$ of cement. The average compressive strength after 28 days is $0.56-$ 1.28 MPa, where the highest compressive strength is found in the sample using $300 \mathrm{~kg} / \mathrm{m}^{3}$ of cement. The average modulus of elasticity after 28 days is in the range 45.74-98.64 $\mathrm{MPa}$, and the highest value of the modulus of elasticity was when using $350 \mathrm{~kg} / \mathrm{m}^{3}$ of cement.

If we compare the results from Table 4 with previous studies shown in Table 2, then we can see that the results obtained for the average volume weight $\left(749\right.$ to $\left.895 \mathrm{~kg} / \mathrm{m}^{3}\right)$, compressive strength $(0.56$ to $1.28 \mathrm{MPa})$, thermal conductivity $(0.47$ to $0.57 \mathrm{~W} / \mathrm{mK})$ and drying shrinkage $(0 \%)$. The compressive strength and volume weight are similar, while the 
results for the thermal conductivity, modulus of elasticity, and drying shrinkage are different.

Therefore, increase in the use of cement in the manufacturing of CLC masonry concrete brick is found not to produce an increase in compressive strength and also resulted in a more severe volume weight of the CLC masonry concrete brick. From this review of the mechanical and physical properties obtained using varying amounts of cement, the best (optimum) result is achieved with the use of $350 \mathrm{~kg}$ of cement.

We give thanks to the Faculty of Engineering Tanjungpura University Pontianak West Kalimantan for support and funding, and to all parties involved in this research.

\section{References}

[1] Hamad, A. J. (2014). Material, production, properties and application of aerated lightweight concrete: Review. International Journal of Materials Science and Engineering, 2 (2), 152-157.

[2] ACI. (1991). ACI Manual of Concrete Practice Part 211.2-91, Standard Practice for Selecting Proportions for Structural Lightweight Concrete. Farmington Hills, MI, USA: ACI.

[3] Supriyadi, A., et al. (2016). Comparison of the masonry concrete brick CLC (Cellular Lightweight Concrete) physical and mechanical properties with variations of sand gradation as the base material. Dipa Research, Department of Civil Engineering, Faculty of Engineering, University of Tanjungpura, Pontianak.

[4] Kumawat, G., Maru, S., \& Kumar Pandey, K. (2016). Cost comparison of RCC structure using heading CLC blocks with burnt clay bricks. International Journal of Advanced Research, 4 (7), ISSN 2320-5407.

[5] Kumawat, G., Maru, S. (2016). Analysis and comparison of RCC structure using heading CLC block with burnt clay bricks. International Journal of Engineering Research and General Science, 4 (3), ISSN 2091-2730.

[6] Krishna Bhavani, K. (2012). Cellular light-weight concrete blocks as a replacement of burnt clay bricks. International Journal of Engineering and Advanced Technology (IJEAT), 2 (2), ISSN: 2249-8958.

[7] Kayyali, A., \& Haque, M. N. (1997). A New Generation of Structural Lightweight Concrete. In V. M. Alhotra (Ed.), Proceedings of Third CANMET/ACI International Conference on Advances in Concrete Technology, ACI SP 171. Auckland, New Zealand.

[8] Ardyansyah, M. (2014). Study of the manufacture of lightweight brick CLC (Cellular Lightweight Concrete) with high levels of coal fly ash as a partial substitution of cement. MT thesis. Sebelas Maret University, Jawa Tengah.

[9] Murdock, U., \& Brook, K. M. (1999). Concrete materials and practice (4th ed.). Jakarta: Erlangga.

[10] Prakash, C. E. (2013). Properties of aerated concrete blocks. International Journal of Scientific and Engineering Research, 4 (1), ISSN 2229-5518.

[11] SNI 7064:2014 (2014). Portland Cement Composites. National Standardization Agency.

[12] Nandi, S., Chatterjee, A., Samanta, P., \& Hansda, T. (2016). Cellular concrete and its facets of application in Civil Engineering. International Journal of Engineering Research, 5 (Special 1), 37-43, ISSN:2319-6890.

[13] Mulyono, T. (2004). Concrete technology. Yogyakarta: Andi. 